\begin{tabular}{ll}
\hline 臨 & 床 \\
\hline
\end{tabular}

\title{
多発性硬化症の誘発耳音響放射および蝸電図
}

\author{
西田 裕明1) ・岡田真由美 ${ }^{2)}$ \\ 井上 庸夫 $\left.{ }^{1}\right) \cdot$ 田中 康夫 ${ }^{1}$
}

\section{Evoked Otoacoustic Emission and Electrocochleogram in a Patient with Multiple Sclerosis}

\author{
Hiroaki Nishida, Tsuneo Inoue and Yasuo Tanaka \\ (Dokkyo University School of Medicine, Koshigaya Hospital) \\ Mayumi Okada \\ (Dokkyo University School of Medicine)
}

A 24-year-old female with multiple sclerosis had right-sided hearing impairment with tinnitus. She underwent electrocochleography (ECochG) and examination of evoked otoacoustic emission (EOAE) to assess cochlear function.

An acoustic probe, type K-3, prepared to measure EOAEs was inserted into the external ear canal. ECochG-AP and CM were recorded by a transtympanic needle electrode technique. The CM and AP were recorded simultaneously and separated into their respective two channels in real time operation by the processor programmed for the isolation of the AP and CM. Short tone bursts were employed as acoustic stimulation to evoke both EOAEs and ECochG-CMs. Clicks and short tone bursts were used to measure ECochGAP.

Both fast and slow components of EOAEs appeared in either the period of deteriorated hearing acuity or when it was improved. They showed normal detection thresholds and input-output curves during both periods.

ECochG-CMs with almost normal detection thresholds and input-output functions were obtained during the period of deteriorated hearing acuity. Delayed CMs with normal delay times and normal detection thresholds were observed during both periods.

$\operatorname{AP}\left(\mathrm{N}_{1}\right)$ input-output curves during relapse with hearing loss were notably lower in amplitude and longer in latency than those obtained at the time hearing impairment showed improvement.

The EOAE and ECochG findings suggested that this patient had almost normal cochlear function, and we assumed from the MRI and ABR findings as well as the ECochG that the hearing impairment was caused by dysfunction of auditory pathways in the brainstem, including involvement of $\operatorname{AP}\left(\mathrm{N}_{1}\right)$ levels.

Key words: evoked otoacoustic emission, electrocochleogram, multiple sclerosis

1）獨協医科大学越谷病院耳鼻咽喉科

2）獨協医科大学耳鼻咽喉科学教室 


\section{はじめに}

多発性硬化症 (multiple sclerosis ; 以下 MS と略す) は中枢神経系の脱髄性疾患で, 病巣も 多巣性に散在していることが多いために多彩な 臨床症状を示す1)。しかし，MS で初発症状とし て，あるいは経過中に難聴，耳鳴が発現寸る頻 度は，報告者によって異なるが大体 $10 \%$ 以内で， 比較的に少ない症状とされている2て4).

一般にMSに打ける難聴は後迷路性難聴と いわれているが，これは大部分が聴覚心理学的 手法による検査，並びに他覚的聴力検査，とり わけ聴性脳幹反応 $(\mathrm{ABR})$ から得られた成績に 基づいたものである.

我々は右半身の錐体路障害および右視神経萎 縮と純音聴力の変動を示した MS の一症例に 誘発耳音響放射 (evoked otoacoustic emission; $\mathrm{EOAE})$ と蝸電図検査を行い，本症例の蝸牛機 能について検討したので報告する。

\section{症例}

患者 : 24歳，女性.

主訴 : 右耳鳴.

家族歴・既往歴：特記すべきことなし.

現病歴: 平成 3 年 9 月頃より両下肢の脱力感 (左>右)に気付き，同時に歩行障害が発現した が放置していた。同年10月30日，突然右視力低 下が出現したため眼科を受診し，右球後視神経 炎の診断をらけた。 またその頃よりフラフラ感， 両側上肢のしびれ感が出現するよらになったた め, 翌31日, 当院神経内科に入院し, 精査の結 果 MS と診断され，同時に治療としてステロ イドの投与が行われた。

平成 4 年 2 月中旬頃より時々回転性めまいや 嘔気が出現していたが，同年 3 月 6 日より右難 聴，耳鳴(キーン)に気付くようになったため, 3 月 7 日当科を紹介された.

耳鼻咽喉科および神経耳科的検査所見：両側 鼓膜正常, 鼻腔 - 咽喉頭異常なし, 角膜反射 咽頭反射正常, 顔面知覚異常なし, 顔面神経麻 㽻なし，下肢の病的反射あり(左>右)，小脳性 失調あり。
純音聴力は初診時 ( 3 月 7 日) 右耳に軽度難聴 を認めたが， 3 週間後の検査では左右差がほと んどないまでに改善した(図 1)。 。聴力の改 善を示した頃より耳鳴も消失した。

初診時の SISI テストは右耳で $1 \mathrm{kHz}$ : $0 \%$, $4 \mathrm{kHz}: 5 \%$, 左耳では $1 \mathrm{kHz}: 30 \%, 4 \mathrm{kHz}$ : $50 \%$ であった．自記オージオグラムは右耳が 4 $\mathrm{kHz}$ で Jergerの III型を示した．ティンパノグ ラムは両側ともA型であった。

アブミ骨筋反射は，右耳対側刺激： $95 \mathrm{~dB}$, 同側刺激 : $85 \mathrm{~dB}$, 左耳対側刺激 : $90 \mathrm{~dB}$, 同 側刺激 : $90 \mathrm{~dB}$ であった.

ENG 所見：3 月 9 日の ENG 検査では純回 旋性と思われる右向きの頭位眼振が認められた。 OKP は右向きの解発が不良で, ETT は右方向 で saccadic pursuitを示していた。温度眼振反 応は右 DPを示し， visual suppression は右50 $\%$ ，左33\%であった。

ABR 所見：聴力低下時および改善時の 90 $\mathrm{dBnHL}$ に対する $\mathrm{ABR}$ 所見を図 2 に示した。 左耳刺激による左耳からは各波ともに正常な反 応が記録されたが，右耳刺激による右耳からは 聴力低下時には I 波とV 波のみしか記録されず, かつ V 波の潜時は $8.68 \mathrm{~ms}$ (左耳：5.60 ms), $\mathrm{I}$-V波間は $7.08 \mathrm{~ms}$ (左耳： $4.28 \mathrm{~ms}$ ) と左耳に 比べ著しい潜時の延長が認められた(左図)。聴 力改善時は右耳に执いて II波执よび而波と思わ

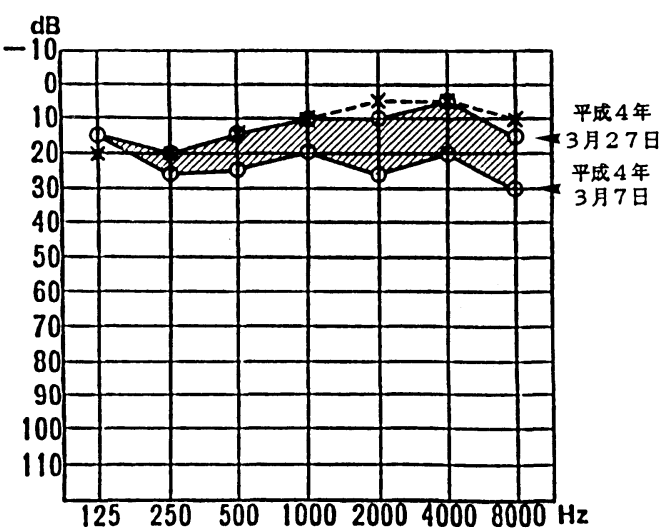

図1 純音オージオグラム 


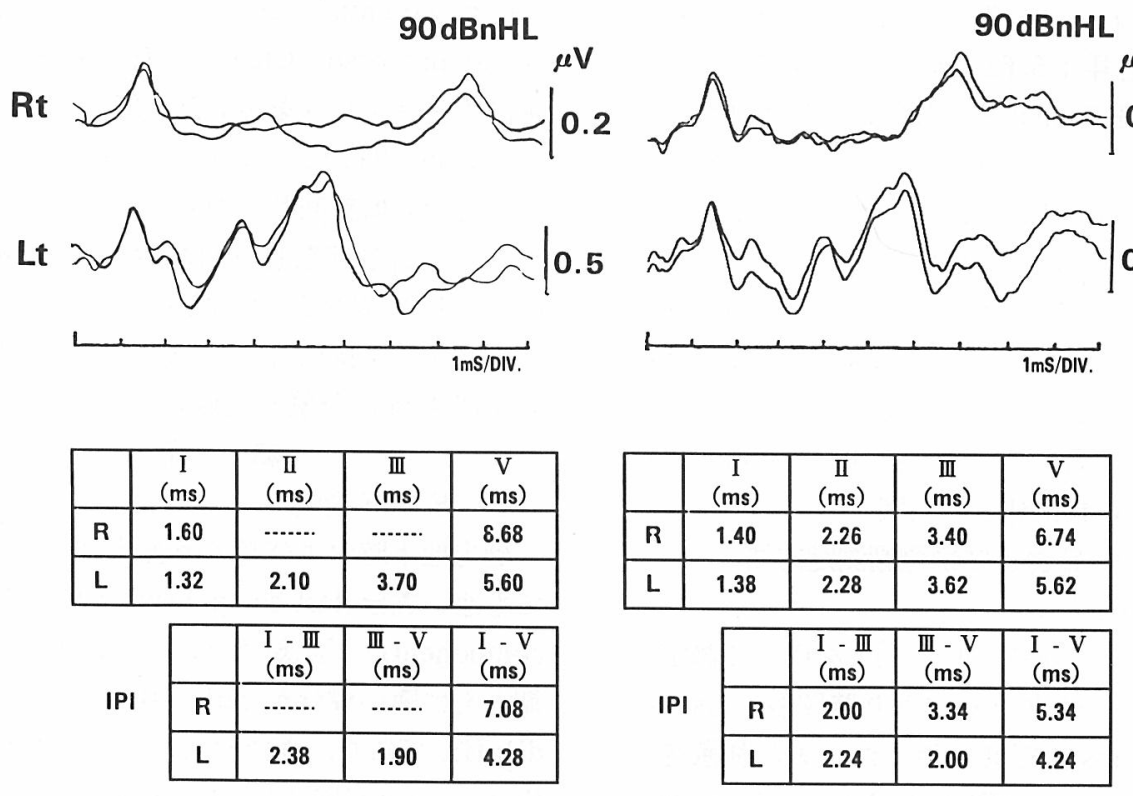

図 $2 A B R$

聴力低下時(左図)は右耳ではI，V波のみしか記録されず，V波の潜時の著しい延長がみ られる. 聴力改善時(右図)には右耳に叔いてII，而波と思われる反応がわずかに出現して いるが，V波の潜時は左耳に比べ依然延長を示している.さらに聴力低下時の I 波の出力 電位は $0.16 \mu \mathrm{V}$, 聴力改善時は $0.45 \mu \mathrm{V}$ で両時期に括いて I 波の出力電位に著しい差がみ られている.
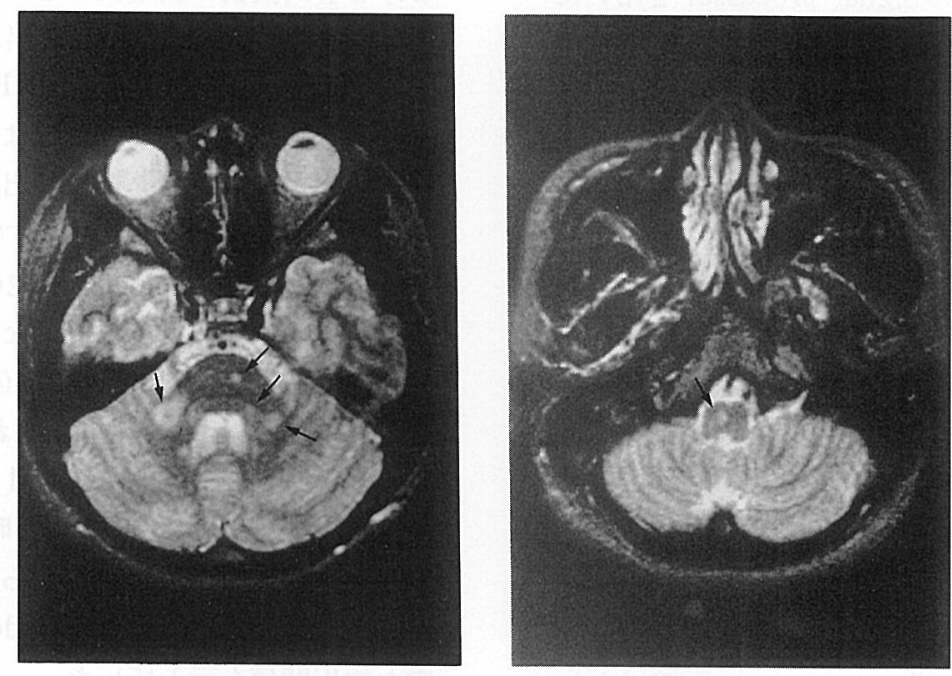

図 3 MRI

小脳, 脳幹部の $\mathrm{T}_{2}$ 強調像. 小脳脚付近に高信号の陰影が数力所に認 められる(左図，矢印)。右上オリーブ核付近にも高信号の陰影がみら れる(右図, 矢印). 
れる反応がわずかにみられたが，V波の潜時は $6.74 \mathrm{~ms}$ (左耳：5.62 ms)，I－V波間は5.34 $\mathrm{ms}$ (左耳： $4.24 \mathrm{~ms}$ ) と左耳に比べ依然延長を示 していた(右図). 右耳に拈けるI 波の出力電位 は聴力低下時 $0.16 \mu \mathrm{V}$, 聴力改善時 $0.45 \mu \mathrm{V}$ と 両時期において出力電位に著しい差がみられた。

MRI 所見: $T_{2}$ 強調像による小脳, 脳幹部の MRIを図 3 に示した. 小脳脚付近に高信号を 呈する陰影が数力所に認められ (図 3-左図), また脳幹では右上オリーブ核付近に高信号を示 す陰影がみられた(図 3-右図)。

\section{EOAE および蝸電図測定方法}

\section{1. $\mathrm{EOAE}$}

音響プローブ K-3（リオン）占）用いて測定し た。刺激音には立上り立下り時間各 $1 \mathrm{~ms}$, 総 持続時間 $3 \mathrm{~ms}$ の短音を用いた。 また刺激音は function generator (FG143, NF) と signal processor (7S11, 三栄測器) に内蔵されている音刺 激装置より発生させた.刺激周波数は $45 \mathrm{dBnHL}$ の音圧に対し反応が最も明瞭に記録される周波 数 (best frequency; BF) を用いた。な拐, 本症 例の $\mathrm{BF}$ は $1 \mathrm{kHz}$ であった．反応の記録およ び解析には上述の signal processorを用いた。 すなわち前置増幅器からの出力信号を, 先ず通 過帯域周波数を $800 \mathrm{~Hz} \sim 3 \mathrm{kHz}(24 \mathrm{~dB} /$ oct) に 設定したフィルタ (multifunction decade filter, E-3201A，NF) を通し signal processor に入力 した. 次いで, 本入力信号を解析時間 $20 \mathrm{~ms}$, 加算回数256回として解析し, 得られた反応を X-Yレコーダに記録した.

\section{2 . 蝸電図}

針電極 HN-3 (ユニークメディカル)を用い鼓 室内誘導法で測定を行った。刺激音は音刺激装 置 SSS-3200 改良型 (日本光電)を用い, 立上り 立下り時間各 $1 \mathrm{~ms}$, 総持続時間 $3 \sim 5 \mathrm{~ms}$ の短 音 $(0.5,1,2,4,8 \mathrm{kHz})$ 抢よびクリックを被検 耳の外耳道入口部より $50 \mathrm{~cm}$ の距離に沶いた スピーカ (FD101, Fostex)より与えた.

蝸牛マイクロホン電位 (cochlear microphonics; CM), 聴神経複合活動電位 (compound action potential; AP)の記録拈よび解析には signal processor ER 1100 (日本電気三栄)の蝸 電図用プログラムを用いた．即ち二つのチャン ネル $(1 \mathrm{ch}, 2 \mathrm{ch})$ に，位相のみが $180^{\circ}$ 異なる刺 激音を用い偶数回数目の刺激音に対する信号を $1 \mathrm{ch}$ に, 奇数回数目 (偶数回数目とは刺激音の 位相が $180^{\circ}$ 異なる)の刺激音に対する信号を $2 \mathrm{ch}$ に入力し, 同時間内で $\mathrm{CM}$ と $\mathrm{AP}$ を各々 $3 \mathrm{ch}$ 拈よび $4 \mathrm{ch}$ に分離し記録した。

\section{結 果}

\section{EAOE 所見}

聴力低下時および聴力改善時のいずれにおい ても速い成分 (fast component) 之遅い成分 (slow component $)^{6)}$ が記録され，その検出閾值は両時 期ともに速い成分が $0 \mathrm{dBnHL}$ ，遅い成分が -5 $\mathrm{dBnHL}$ であり，両成分ともに正常な反応が検 出されていた(図 4). また入出力曲線において も両時期に打ける速い成分, 遅い成分ともにほ とんど差がみられなかった(図 5 )。

\section{2 . 蝸電図所見}

$\mathrm{CM}$ : 聴力低下時と聴力改善時の $1 \mathrm{kHz}$ の $\mathrm{CM}$ 波形と入出力曲線を図 6 亿，また両時期に 打ける各周波数の反応波形を図 7 に示した。両 時期に打忊る各周波数の検出閾值は $0.5 \mathrm{kHz}$ と $8 \mathrm{kHz}$ に聴力低下時に $20 \mathrm{~dB}$ の閾值の上昇 がみられたが，他の周波数では検出閾值には差 がみられなかった。しかし検出閾值に差がみら れた $0.5 \mathrm{kHz}$ と $8 \mathrm{kHz}$ の $\mathrm{CM}$ では最大音圧 90 $\mathrm{dBnHL}$ に扮ける出力電位は他の周波数と同様 に両時期において差がみられなかった。

遅延反応 (delayed $\mathrm{CM})^{7)}$ は $0.5 \mathrm{kHz}, 1 \mathrm{kHz}$ および $2 \mathrm{kHz} て ゙$ 両時期にいずれも明瞭に認め られた。またこれらの delayed CM の検出閾値 は $0.5 \mathrm{kHz}$ に打いて聴力改善時に比べ聴力低 下時に $20 \mathrm{~dB}$ 閾值の上昇がみられたが, $1 \mathrm{kHz}$, $2 \mathrm{kHz}$ では, 両時期における delayed CM は正 常な検出閾值を示していた。

$\mathrm{AP}: 2 \mathrm{kHz}$ およびクリック刺激による $\mathrm{AP}$ $\left(\mathrm{N}_{1}\right)$ の入出力曲線を図 8 に，またその他の周波 数に扣ける $\mathrm{AP}\left(\mathrm{N}_{1}\right)$ の振幅および潜時を表 1 に 
$\mathrm{dBnHL}$

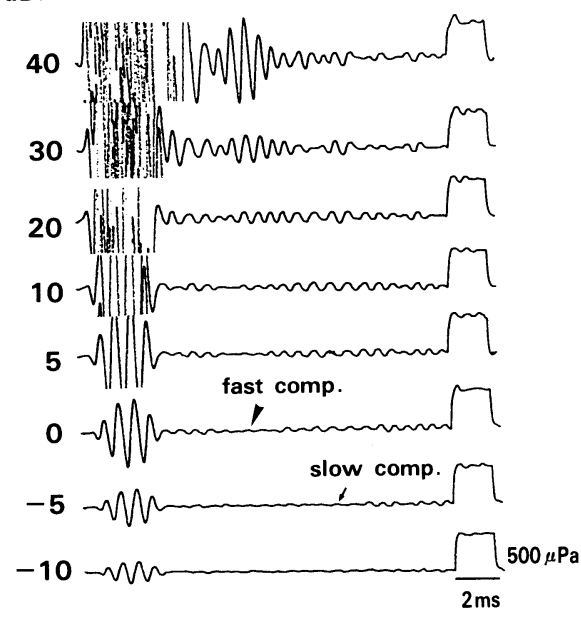

dBnHL

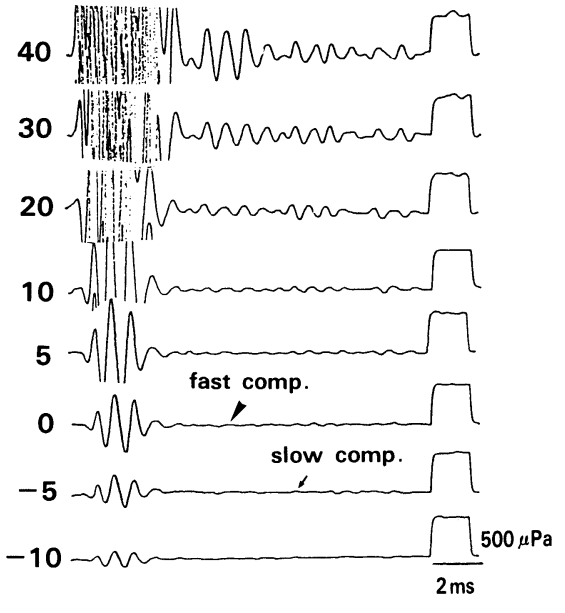

図 $4 \mathrm{EOAE}$ 波形

聴力低下時 (左図), 聴力改善時 (右図) ともに fast component (速い成分) が $0 \mathrm{dBnHL}$ より slow component(遅い成分)が $-5 \mathrm{dBnHL}$ より検出されている.

刺激周波数 : $1 \mathrm{kHz}$
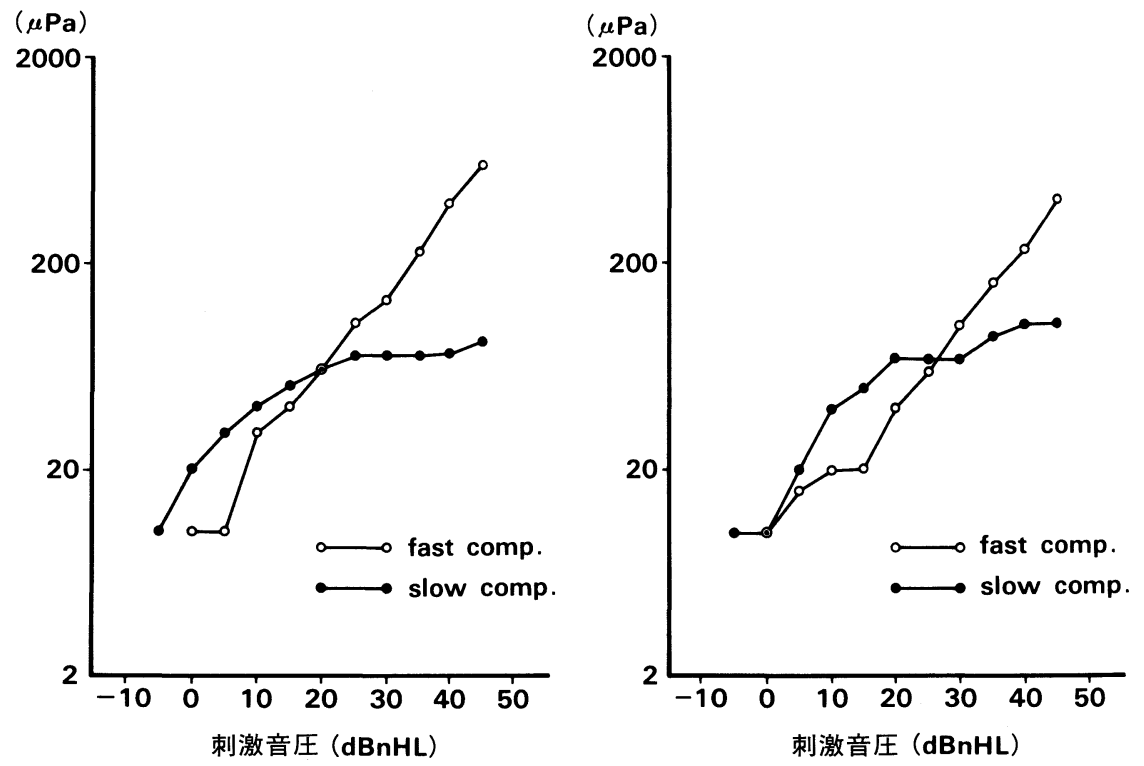

図 5 EOAE 入出力曲線

聴力低下時 (左図), 聴力改善時 (右図)の入出力曲線は fast component (速い成分), slow component (遅い成分) ともに両時期においてほとんど差がみられていない. 
示した. $2 \mathrm{kHz}$ 抢よびクリック刺激による $\mathrm{AP}$ $\left(\mathrm{N}_{1}\right)$ の入出力曲線はいずれも $\mathrm{L}, \mathrm{H}$ の両 $\mathrm{part}^{8)}$ を示していたが，聴力低下時のそれは聴力改善 時に比べ振幅が著しく低かった. 最大刺激音圧 $90 \mathrm{dBnHL}$ に対する両時期の振幅を比較すると 聴力低下時の振幅は $0.5 \mathrm{kHz}: 10.2 \mu \mathrm{V}$ (聴力 改善時 $34.7 \mu \mathrm{V}), 1 \mathrm{kHz}: 6.8 \mu \mathrm{V}$ (同 $39.1 \mu \mathrm{V}$ ), $2 \mathrm{kHz}: 8.0 \mu \mathrm{V}$ (同 $43.2 \mu \mathrm{V}$ ), $4 \mathrm{kHz}: 12.9 \mu \mathrm{V}$ (同 $44.0 \mu \mathrm{V}$ ), $8 \mathrm{kHz}: 14.1 \mu \mathrm{V}$ (同 $50.1 \mu \mathrm{V}$ ), ク リック: $35.0 \mu \mathrm{V}($ 同 $90.0 \mu \mathrm{V})$ といずれの刺激 音に対しても聴力低下時の電位は聴力改善時に 比べ 3 分の 1 あるいはとれ以下と著しく低かっ た。一方，振幅と同じ音圧 $90 \mathrm{dBnHL}$ に対す る両時期の潜時について比較すると聴力低下時 は $0.5 \mathrm{kHz}: 3.6 \mathrm{~ms}$ (聴力改善時 $2.5 \mathrm{~ms}$ ), 1 $\mathrm{kHz}: 2.6 \mathrm{~ms}$ (同 $1.8 \mathrm{~ms}$ ), $2 \mathrm{kHz}: 2.0 \mathrm{~ms}$ (同
$1.8 \mathrm{~ms}), 4 \mathrm{kHz}: 1.9 \mathrm{~ms}$ (同 $1.4 \mathrm{~ms}), 8 \mathrm{kHz}$ ： $1.3 \mathrm{~ms}$ (同 $1.1 \mathrm{~ms}$ ), クリック : $1.2 \mathrm{~ms}$ (同 1.1 $\mathrm{ms})$ と聴力改善時に比べて潜時の延長がみられ た。

\section{考察}

MS に拈ける聴覚系の障害部位は後迷路性で， 多くは脳幹部にあるといわれている9)。しかし 脳幹の正確な障害部位は必ずしも解明されてい ないが，剖検例10111), ABR 所見，さらに近年著 しい進歩がみられる MRI 等の画像所見より障 害部位がかなり正確に診断されるに至っている。 即ち，これらの所見に基づいた報告をまとめて みると大脳皮質下 $(\text { 側頭葉白質 })^{12}$, 脳質周辺白 質13)，中脳下丘，蝸牛神経核や第 8 脳神経根入

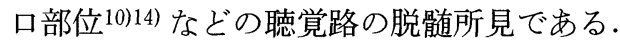

MS は中枢神経系の障害で末梢器官は障害さ
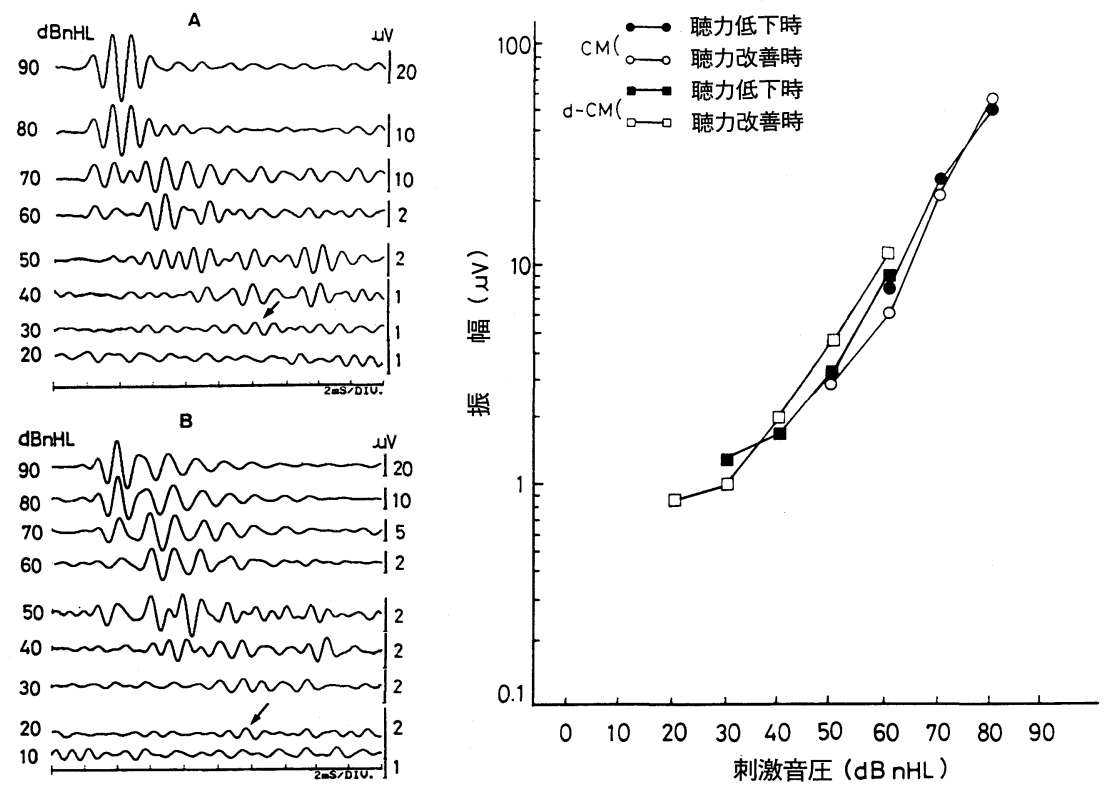

図 $6 \mathrm{CM}$ 波形と入出力曲線 $(1 \mathrm{kHz})$

delayed CM の検出閾値は聴力低下時(左図-A) が $30 \mathrm{dBnHL}$, 聴力改善時 (左図B)が $20 \mathrm{dBnHL}$ で両時期ともに明瞭な delayed CM が記録されている. 矢印 : delayed CM

入出力曲線(右図)に拈いては CM, delayed CM ともに両時期に拈ける差はなく 出力電位は正常範囲内にある。 d-CM : delayed CM 
A

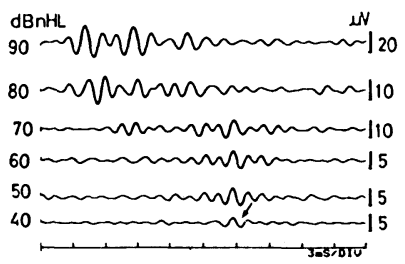

A

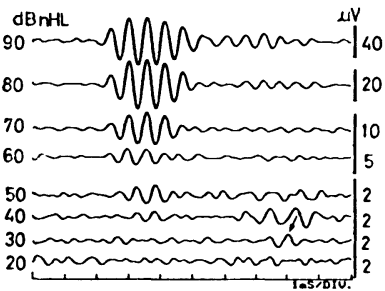

$2 \mathrm{kHz}$

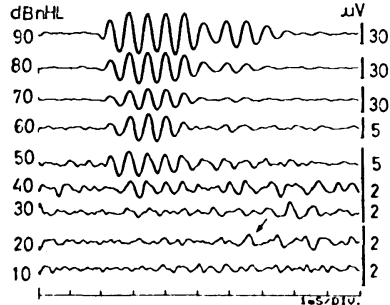

A

$4 \mathrm{kHz}$

B
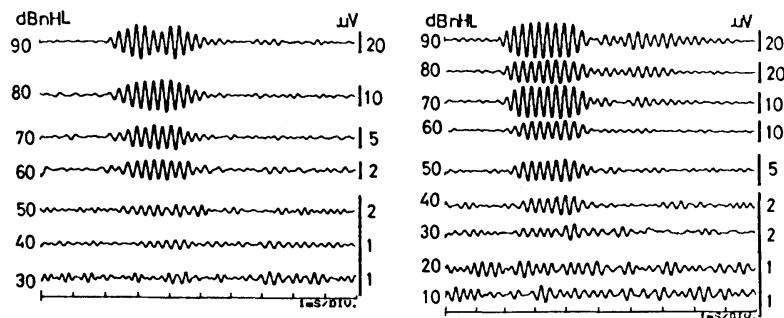

A

$8 \mathrm{kHz}$
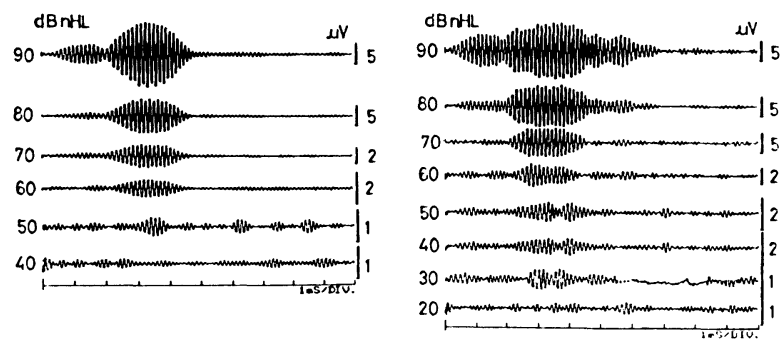

図 $7 \mathrm{CM}$ 波形

$0.5,2,4,8 \mathrm{kHz}$ の刺激音に対する聴力低下時 (A) と聴力改 善時 $(\mathrm{B})$ の $\mathrm{CM}$ 波形を示す.

$0.5,2 \mathrm{kHz}$ の $\mathrm{CM}$ 波形は聴力低下時および聴力改善時の両 時期に执いて明瞭な delayed CM が記録されている. $4 \mathrm{kHz}$, $8 \mathrm{kHz}$ に执いては delayed CM は記録されていないが，両時 期に和ける CM の出力電位には差が汪とんどみられていない. 矢印 : delayed CM 
れない15)といわれていることと，通常の聴覚 心理学的手法による検査では末梢蝸牛の機能を 詳細に知ることが困難であったことなどが相俟 って，本疾患における蝸牛機能の詳細な報告は 未だみることができない，

ヒトの蝸牛の機能を客観的に評価する方法と しては，蝸牛に打ける電気現象の記録，即ち蝸 電図法と蝸牛の音響的反応の記録，つまり耳音 響放射の二つが現在のところ最も有効な方法と 考えられる616)。

本症例に打けるSISI テスト，自記オージオ グラム等は後迷路性難聴の所見であり，さらに $\mathrm{MRI} \mathrm{T}_{2}$ 強調像で脳幹部の右上オリーブ核付近 に脱䯣性の変化をらかがわせる高信号の陰影が 認められること，ABR に打ける而波の欠如， $\mathrm{V}$ 波の潜時の延長および $\mathrm{I}-\mathrm{V}$ 波間の延長など の所見とも考光合わせると，本症例の難聴が後 迷路性で，とくに右上オリーブ核付近に主病変 をもった脳幹部の障害による後迷路性の難聴障 害であることを裏付けるものであった。しかし 末梢蝸牛には従来の報告で述べられているよう

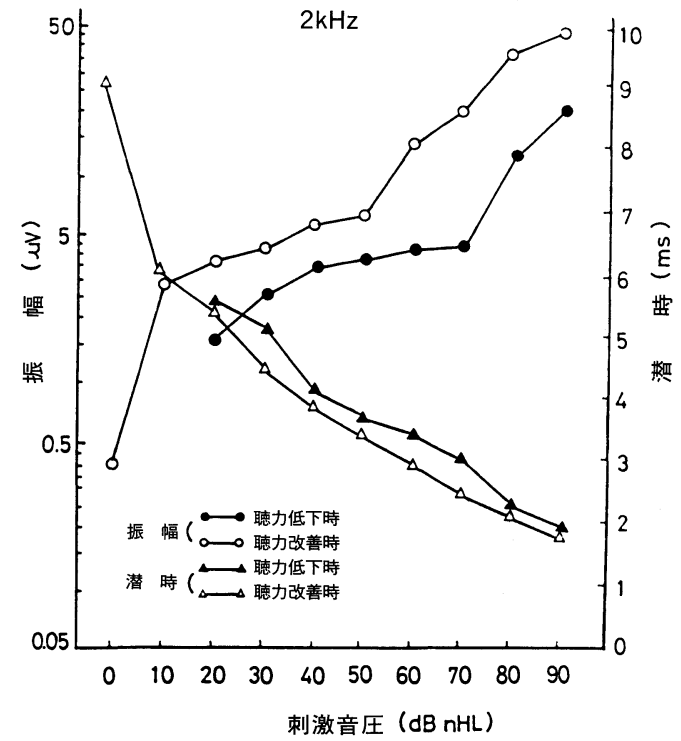

に何の障害も生じていないのかについて検討す る必要がある。

本症例の $\mathrm{EOAE}$ は聴力低下時と聴力改善時 のいずれに拈いても速い成分と遅い成分の両成 分を有する反応が記録され，これらの成分の検 出閾值拉よび入出力曲線は両時期とも差がみら れず正常範囲17) 内にあった。 また蝸電図 CM に扮いても両時期に反応の差はほとんどなく， $0.5 \mathrm{kHz}$ 执よび $8 \mathrm{kHz}$ に抮ける聴力低下時に 出力電位の軽度低下 $(90 \mathrm{dBnHL}$ では両時期に 打ける振幅には差がなかった)を示した以外は， いずれの周波数に拉いても検出閾値, 入出力曲 線ともに正常範囲内にあった. さらに両時期と もに delayed CM が記録され，この delayed $\mathrm{CM}$ の周波数特性や入出力曲線は注ぼ正常であ り，また検出閾値に扮いても $0.5 \mathrm{kHz}$ に括け る聴力低下時以外はいずれも正常な值を示して いた。

EOAE は入力音に対する蝸牛基底板の微小 機械系振動の共鳴が逆向きに投射された音響的 反応であり，その起源は代謝依存性の外有毛細

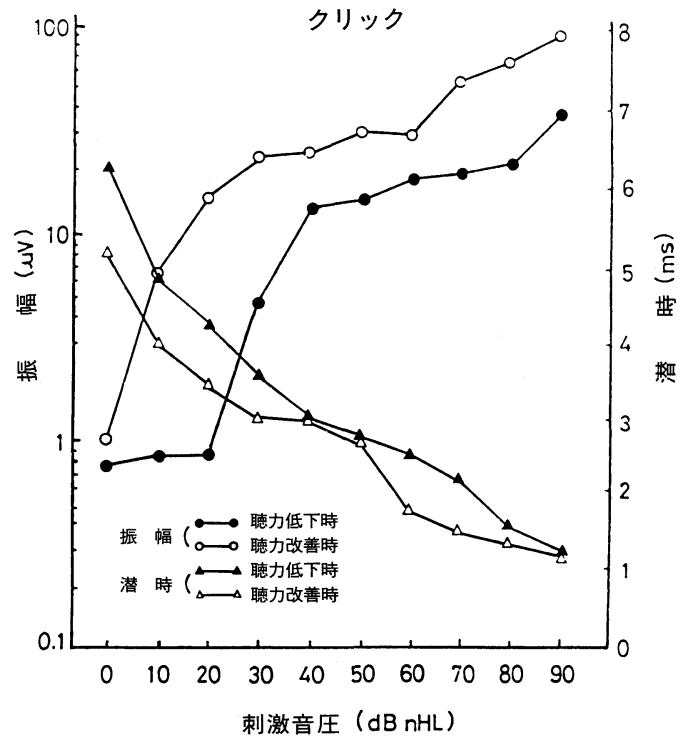

図 $8 A P\left(\mathrm{~N}_{1}\right)$ 入出力曲線

$2 \mathrm{kHz}$ (左図)，クリック(右図)刺激による $\mathrm{AP}\left(\mathrm{N}_{1}\right)$ の入出力曲線は L-part および H-part の両 part を 示しているが，聴力低下時の振幅は聴力改善時に比べ著しく低い. 
胞がオリーブ蝸牛束 (OCB) と連係した能動的 過程による反応と考えられている18)19).

CM はラセン器に打ける感覚毛の振動に由来 する電位であり, 最近, 本電位を短音を用いて 記録すると弱刺激下で遅れて記録される現象， 即ち遅延反応 (delayed CM) がみられている7). この delayed $\mathrm{CM}$ と EOAE に扝ける遅い成分 には潜時や入出力曲線上に類似性があり, 両者 が同一起源に由来する反応ではないかと考觉ら れている20). 本症例に拈けるEOAE 扣よび蝸 電図 CM はいずれもほ注正常な反応を示して 扣り，蝸牛に括ける電気的执よび音響的反応か
らみると蝸牛の有毛細胞は正常に機能している と思われた。

一方, 蝸電図 $\mathrm{AP}\left(\mathrm{N}_{1}\right)$ はいずれの刺激音に対 しても聴力低下時と聴力改善時では出力電位, 潜時ともに著しい差がみられた。即ら聴力低下 時には出力電位の低下と潜時の延長がみられた．

$\mathrm{AP}\left(\mathrm{N}_{1}\right)$ の聴力正常耳に括ける出力電位およ び潜時は鼓室内誘導法による記録では個体差が 大きく，とくに振幅においてその傾向が強い。 しかし同一被検者の同側耳に複数回測定を行っ た場合は電極間抵抗値が $10 \mathrm{k} \Omega$ 以内の安定し た状態で記録を行えば検出閾值は $10 \mathrm{~dB}$ 以内

表 1 各周波数別にみた $\mathrm{AP}\left(\mathrm{N}_{1}\right)$ の振幅执よび潜時

\begin{tabular}{c|c|c|c|c}
\hline \hline \multicolumn{5}{c}{$0.5 \mathrm{kHz}$} \\
\hline \multirow{2}{*}{$\mathrm{dBnHL}$} & \multicolumn{5}{|c}{ 聴力低下時 } & \multicolumn{2}{|c}{ 聴力改善時 } \\
\cline { 2 - 5 } & 振幅 $(\mu \mathrm{V})$ & 潜時 $(\mathrm{ms})$ & 振幅 $(\mu \mathrm{V})$ & 潜時 $(\mathrm{ms})$ \\
\hline 90 & 10.2 & 3.6 & 34.7 & 2.5 \\
80 & 8.7 & 3.9 & 26.0 & 2.6 \\
70 & 3.9 & 4.9 & 12.6 & 2.8 \\
60 & 1.5 & 6.1 & 10.9 & 3.4 \\
50 & 0.7 & 6.1 & 7.0 & 3.9 \\
40 & & & & \\
30 & & & & \\
20 & & & &
\end{tabular}

\begin{tabular}{c|c|c|c|c}
\hline \hline \multicolumn{5}{c}{$4 \mathrm{kHz}$} \\
\hline \multirow{2}{*}{$\mathrm{dBnHL}$} & \multicolumn{3}{|c}{ 聴力低下時 } & \multicolumn{2}{|c}{ 聴力改善時 } \\
\cline { 2 - 5 } & 振幅 $(\mu \mathrm{V})$ & 潜時 $(\mathrm{ms})$ & 振幅 $(\mu \mathrm{V})$ & 潜時 $(\mathrm{ms})$ \\
\hline 90 & 12.9 & 1.9 & 44.0 & 1.4 \\
80 & 6.9 & 2.1 & 35.9 & 1.7 \\
70 & 1.6 & 2.8 & 17.9 & 1.9 \\
60 & 2.3 & 3.0 & 9.4 & 2.2 \\
50 & 2.9 & 3.5 & 5.0 & 2.6 \\
40 & 1.1 & 3.8 & 4.6 & 3.2 \\
30 & 0.5 & 4.5 & 4.1 & 3.6 \\
20 & & & 3.0 & 4.1 \\
10 & & & 1.4 & 4.6 \\
0 & & & &
\end{tabular}

\begin{tabular}{c|c|c|c|c}
\hline \multicolumn{5}{|c}{$1 \mathrm{kHz}$} \\
\hline \multirow{2}{*}{$\mathrm{dBnHL}$} & \multicolumn{3}{|c}{ 聴力低下時 } & \multicolumn{2}{|c}{ 聴力改善時 } \\
\cline { 2 - 5 } & 振幅 $(\mu \mathrm{V})$ & 潜時 $(\mathrm{ms})$ & 振幅 $(\mu \mathrm{V})$ & 潜時 $(\mathrm{ms})$ \\
\hline 90 & 6.8 & 2.6 & 39.1 & 1.8 \\
80 & 3.7 & 3.0 & 33.6 & 2.1 \\
70 & 2.6 & 3.6 & 13.5 & 2.5 \\
60 & 2.4 & 4.5 & 8.4 & 3.0 \\
50 & 1.9 & 5.0 & 4.1 & 3.3 \\
40 & 1.4 & 6.1 & 3.5 & 3.8 \\
30 & & & 3.2 & 4.8 \\
20 & & & 3.6 & 5.4 \\
10 & & & 1.3 & 6.1 \\
0 & & & &
\end{tabular}

\begin{tabular}{c|c|c|c|c}
\hline \multicolumn{5}{c}{$8 \mathrm{kHz}$} \\
\hline \multirow{2}{*}{$\mathrm{dBnHL}$} & \multicolumn{3}{|c}{ 聴力低下時 } & \multicolumn{2}{|c}{ 聴力改善時 } \\
\cline { 2 - 5 } & 振幅 $(\mu \mathrm{V})$ & 潜時 $(\mathrm{ms})$ & 振幅 $(\mu \mathrm{V})$ & 潜時 $(\mathrm{ms})$ \\
\hline 90 & 14.1 & 1.3 & 50.1 & 1.1 \\
80 & 10.7 & 1.6 & 33.9 & 1.3 \\
70 & 4.6 & 2.1 & 21.7 & 1.5 \\
60 & 3.7 & 2.3 & 11.0 & 2.0 \\
50 & 2.5 & 2.5 & 8.0 & 2.3 \\
40 & 2.6 & 2.9 & 8.0 & 2.3 \\
30 & 2.1 & 3.2 & 5.5 & 2.9 \\
20 & 0.8 & 3.7 & 3.4 & 3.1 \\
10 & & & & \\
0 & & & &
\end{tabular}


に, 最大刺激強度 $(90 \mathrm{dBnHL})$ における振幅は $5 \mu \mathrm{V}$ 以内に, 潜時も $0.2 \mathrm{~ms}$ 以内といずれも 安定した反応を記録することができる211.

MSに扣いて聴神経の末梢側が障害されると， $\mathrm{ABR}$ で I 波の消失4) ${ }^{4} \mathrm{AP}$ に異常22) がみられ るといら報告があり，これらの ABR 異常所見は剖検例10)11) や MRI ${ }^{13)}$ により第 8 脳 神経の神経根入口部位の脱䯣によるものと説明 されている. 今回の我々の症例に沶いて MRI では第 8 脳神経根入口部位の検索はでさなかっ たが，聴力低下時の AP 所見が聴力改善時に比 べて著しく低い出力電位と潜時の延長を示して おり, 本症例では蝸牛神経の脱髄が $\mathrm{AP}\left(\mathrm{N}_{1}\right)$ レ ベルにまで及んでいるものと推測した.

\section{まとめ}

多発性硬化症の一症例 (24歳, 女性) に誘発耳 音響放射の測定および蝸電図検査を行い, 蝸牛 機能について検討した。

1. $\mathrm{EOAE}$ は聴力低下時, 聴力改善時の両 時期ともに速い成分および遅い成分が記録され， 両時期におけるこれらの成分は正常な検出間值 および入出力曲線を示していた。

2. 蝸電図 CM は聴力低下時および聴力改 善時においてほぼ正常な検出閾值叔よび入出力 曲線が得られ，また両時期のいずれにも delayed $\mathrm{CM}$ が記録された。

3 . 聴力低下時の $\mathrm{AP}\left(\mathrm{N}_{1}\right)$ の入出力曲線は聴 力改善時に比べ出力電位に著しい低下がみられ, また聴力低下時には潜時の延長がみられた。

4. EOAE 抽よび蝸電図所見から, 本症例 では蝸牛のラセン器は汪ぼ正常に機能して沶り, 聴覚系の障害は聴神経より右上オリーブ核付近 に主病変をもった脳幹部に至る聴覚路にあるも のと推測した.

本論文の要旨は第 2 回日本耳科学会臨床学会総会 に批いてロ演した。

\section{文 献}

1) Grenman $R:$ Involvement of the audiovestibular system in multiple sclerosis; an otoneurologic and audiologic study. Acta Otolaryngol (Stockh) Suppl $420: 1 \sim 95,1985$.

2) Kahana E, Leibowitz $U$ and Alter $M$ : brainstem and cranial nerve involvement in multiple sclerosis. Acta Neuro Scand $49: 269$ $\sim 279,1973$.

3) Müller R : Studies on disseminated sclerosis with special reference to symptomatology, course and prognosis. Acta Med Scand Suppl $222: 1 \sim 214,1949$.

4) Fischer $\mathrm{C}$, Mauguière $\mathrm{F}$, Ibanez $\mathrm{V}$, et al : The acute deafness of definite multiple sclerosis; BAEP patients. Electroencephalogr Clin Neurophysiol $61: 7 \sim 15,1985$.

5）井上庸夫, 田中康夫, 鈴木雅一, 他 : 誘発耳音 響放射測定用プローブ K-3. Ear Res Jpn 21 : 237 238, 1990.

6) Tanaka $Y$, Suzuki $M$ and Inoue $T$ : Evoked otoacoustic emissions in sensorineural hearing impairment; its clinical implication. Ear Hear 11 : 134 143, 1990.

7) Nishida $H$, Okada $Y$ and Tanaka $Y$ : Delayed responses in ECoG. First International Conference on $\mathrm{ECoG}, \mathrm{OAE}$ and Intraoperative Monitoring. Proceeding (in press).

8) Yoshie N, Ohashi $T$ and Suzuki $T$ : Nonsurgical recording of auditory nerve action potential in man. Laryngoscope $77: 76 \sim 85$, 1976.

9) Furman JMR, Durrant JD and Hirsch WL: Eight nerve signs in a case of multiple sclerosis. Am J Otolaryngol $10: 376 \sim 381,1989$.

10) Brock $W$ and Gagel $O$ : Rechtsseitiger Kleinhirnbrückenwinkeltumor-Multiple Sklerose. Eine falsche Diagnose. Arch Ohren-NasenKehlkopfheilkd $134:$ 276 286, 1933.

11) Dix MR : Loudness recruitment and its measurement with special reference to the loudness discomfort level test and its value in diagnosis. Ann Otol Rhinol Laryngol 77 : 1131 $\sim 1151,1968$.

12) Tobira $T$, Tsuji $S$, Nagashima $T$, et al : Cortical deafness in multiple sclerosis. J Neurol Neurosurg Psychiatry 44 : 433 436, 1981. 
13) Curè JK, Cromwell LD, Case JL, et al : Auditory dysfunction caused by multiple sclerosis ; detection with MR imaging. AJNR $11: 817 \sim 820,1990$.

14) Dix MR : Observation upon the nerve fibre deafness of multiple sclerosis with particular reference to the phenomenon of loudness recruitment. J Laryngol Otol $79: 695 \sim 706$, 1965.

15) Barratt HJ, Miller D and Rudge $P$ : The site of the lesion causing deafness in multiple sclerosis. Scand Audiol $17: 67 \sim 71,1988$.

16）西田裕明：蝸電図の臨床応用. 耳鼻臨床 74 ： 117 138, 1981.

17）岡田真由美, 井上良江, 田中康夫：誘発耳音響 放射の遅延成分について. Ear Res Jpn 20：69 $\sim 74,1989$.

18) Khanna SM and Leonard DGB : Basilar membrane tuning in the cat cochlea. Science 215 : 305 306, 1982.
19) Mountain DC : Changes in endolymphatic potential and crossed olivo-cochlear bundle stimulation alter cochlear mechanics. Science $210: 71 \sim 72,1980$.

20) Okada $M$, Nishida $H$ and Tanaka $Y$ : Evoked otoacoustic emissions and delayed microphonic potentials in human ears. International Conference on $\mathrm{ECoG}, \mathrm{OAE}$ and Intraoperative Monitoring. Proceeding (in press).

21）西田裕明：蝸電困記録に打ける artifact の問題. 耳展 26 : 753 757, 1983.

22) Parving $A$, Elbering $C$ and Smith $T$ : Auditory electrophysiology; findings in multiple sclerosis. Audiology $20: 123 \sim 142,1981$.

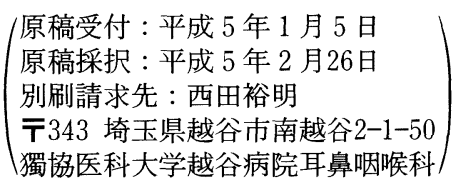

